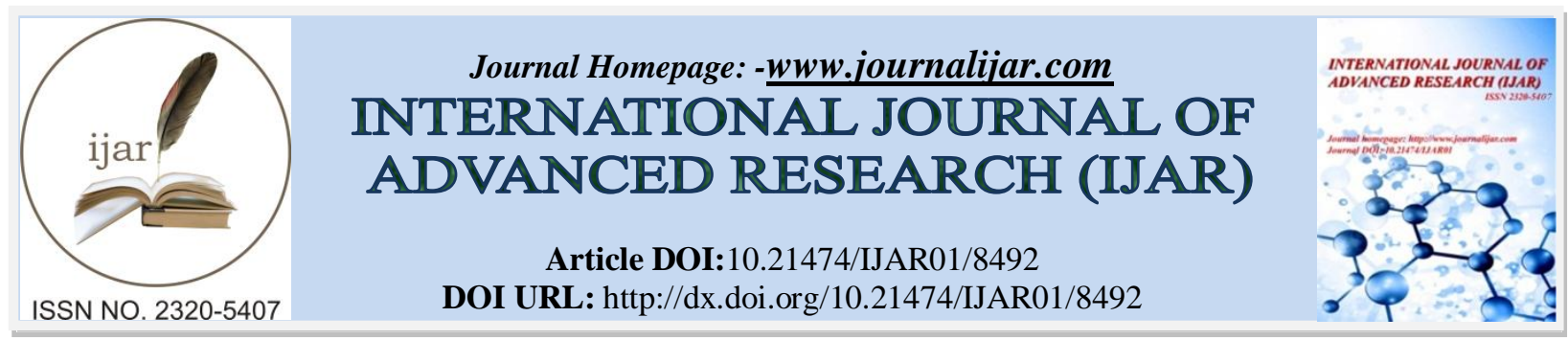

RESEARCH ARTICLE

\title{
IMPACT OF BILATERAL TRADE AGREEMENTS ON RUSSIA'S POSITION AS AN EXPORT PARTNER OF SYRIA.
}

Ali Faysal Ebraheem and Sameer Radi Sharaf.

Department of Economics and Planning - International Relations, Tishreen University, Lattakia, Syria.

\section{Manuscript Info}

Manuscript History

Received: 04 December 2018

Final Accepted: 06 January 2019

Published: February 2019

Key words:-

Bilateral Trade Agreements, Exports,

Russia, Syria.

\begin{abstract}
This study aims to identify Russia as an export partner of Syria. In order to accomplish this, the descriptive analytical approach was followed in presenting bilateral trade agreements between Syria and Russia, analyzing the structure and direction of Syrian exports to Russia and comparing with Syria's most important trading partners. Statistical methods were used to prove the hypothesis of the study. The study found that Russia is not considered an export partner of Syria. It achieved rank $13^{\text {th }}$ out of 17 countries included, according to the criterion of export partners. It obtained the first and second rank before and after the Syrian crisis in the year 2011, according to the criterion of import partners. The study suggested that the reason behind that is weak trade agreements signed between the two countries.
\end{abstract}

Copy Right, IJAR, 2019,. All rights reserved.

\section{Introduction:-}

Countries seek through their agreements to achieve interests as possible. The economic aspect of these agreements plays a key role in achieving those interests. Countries sign bilateral or multilateral economic agreements that regulate their relations within a legal framework, and guarantee the rights of all parties. These agreements take several forms, First: bilateral trade agreements could facilitate the movement of foreign trade and reduce their costs, leading to increase exchanges and stimulate of productive sectors and markets. Second: bilateral agreements of an investment nature play a role in facilitating the movement of foreign investments, capital, transfers and individuals, as well as enhancing cooperation in certain economic sectors (energy, transportation, underground resources, agriculture, industry, trade, Etc.). Finally: bilateral agreements of a financial nature are useful in providing a system of easy payments for exchanges, such as local currency repayments, open credit lines, commodity exchanges, etc., thus supporting the purchasing power of local currency and disposal of foreign currency dependence. From the previous presentation, we can see the many areas of economic, commercial and scientific cooperation possible through these agreements. Coming to Syrian-Russian bilateral economic agreements, these agreements led to a number of benefits for the Syrian side, some evidences are -in brief-:

\section{Investment Dimension:-}

Syrian government has invited the Russian companies such as Gazprom and Lukoil to help rebuild and develop Syrian infrastructure, oil and gas pipelines. In order to cooperate in areas such as trade, energy and commerce, agreements worth billions of dollars have been signed since the beginning of Syrian crisis in the year 2011, (Khatib, 2016).

Corresponding Author:-Ali Faysal Ebraheem.

Address:-Department of Economics and Planning - International Relations, Tishreen University, Lattakia, Syria. 


\section{Finance Dimension:-}

Bilateral relations strengthened even more after the Vladimir Putin and Bashar al-Assad meeting in Moscow in 2005. The leaders agreed to reduce the Syrian debt ( $\$ 13,4$ billion) by 73 percent, to ( $\$ 3,6$ billion) (Donaldson et al., 2014), and its partial exchange of new contracts for Russian companies, mostly in energy and infrastructure sector. This agreement allowed Syria to purchase large amount of Russian weaponry. Among the previous dimension, this study concentrates on the trade dimension, in particular : Export side.

\section{Trade Dimension: -}

Since 2000, the volume of trade between the two countries has been gradually growing and by 2012 reached ( $\$ 2$ billion) (Kozhanov, 2014). In 2014 Russia was Syria's tenth largest trade partner after: (Iraq, Saudi Arabia, United Arab Emirates, Turkey, Iran, Kuwait, Libya, China and the European Union). Syria had applied to be inducted as a member of a Free Trade Zone with Russia and negotiations were going on for almost two years. In November 2016, the proposal was accepted and a customs corridor has been signed for the trade of agricultural outputs between Syria and Russia, (Ashawi, 2016). Syrian trade with Russia is witnessing a major increase in 2016. The Syrian government is planning to be able to be an industrial centre for Russian products in West Asian region. Russian companies are investing in the telecommunications and technologies sectors in Syria in a huge manner, (Ammar, 2016). Future projects in the commercial sector, the most important of them, is the export village in Lattakia, which is the first and most important step in the economic relations between the two countries. This is a key factor for the development of cooperation between the private sector in both countries. Inside this village, a collection of Syrian exports to Russia and vice versa would be made, and through this village would be the establishment of branches of Russian factories and companies in Syria, and in the second stage would be the establishment of the Syrian Trade House in Russia to support and finance the trade exchange of this village and other joint projects, and the dialogue is in this regard between the businessmen of the two countries, in addition to communication with the Central Bank of Syria waiting to determine the timetable for the start of this project. Upon completion of the export village and the commercial house, it would be become urgent to find sources of financing for projects in the two countries, and then would be opening branches of Russian banks in Syria to finance these projects.

\section{Problem of the Study:-}

Bilateral economic agreements between two countries aim to achieve a range of benefits accruing to both sides of the agreements. However, the problem is not in the objectives of these agreements, which are often included in their terms, but in the real benefits achieved. These benefits may be below the level specified in the agreements, and their sharing may be uneven, i.e., they go in favor of one party more than the other. As well as, the effectiveness of these agreements may be weaken as a result of internal or external influential variables, making them not contribute to the development of bilateral economic relations. By dropping this on the studied issue, Syria's benefits would grow from the bilateral trade agreements signed with Russia, if the latter was an export partner of Syria, i.e., a market for the disposal of Syrian goods and services. Hence the main question is: whether Russia is an export partner of Syria under bilateral trade agreements signed between them?

\section{Importance of the Study:-}

The theoretical importance of this study is that: It takes in details the contents of the bilateral trade agreements signed during the study period and analyzes their effects on Syrian exports to Russia, thus, the study derives its importance from the importance of classification and linkage between trade agreements and foreign trade. The measurement of size and nature of the commercial relationship between Syria and Russia, through comparative analysis, adds importance to the study in that it shows Russia's size as an export partner, as well as being an investment partner and a political ally of Syria.

The practical importance of this study is: to determine the strengths and weaknesses of the Syrian exports to Russia, in order to present proposals that would stimulate and improve these exports so as to achieve maximum benefit for Syria from the Russian economic partner.

\section{Objectives of the study:-}

The present study aims to achieve the followings:

1. Presenting the bilateral trade agreements signed between Syria and Russia during the study period -the current millennium-.

2. Conducting a comparative analysis of Syrian exports to Russia and identify Russia as an export partner of Syria. 


\section{Study Methodology:-}

This study is based on the analytical descriptive approach in presentation and analysis of the bilateral trade agreements, as well as the structure and development of Syrian exports to Russia. Therefore, statistical tools were used (averages, standard deviations, correlation coefficients, regression models, annual and compound growth rates) On foreign trade variables (exports, imports), gross and bilateral, by several classifications.

\section{Study Hypothesis:-}

Syrian-Russian bilateral trade agreements have contributed to the improvement of Syrian exports in quantity and quality, so that Russia has become an export partner of Syria.

\section{Literature Review:-}

A study by (Almadani, 2014), tried to understand the nature of the relations between Syria and Russia, and discussed the reasons for the Russian intervention in the Syrian crisis through several axes. The first was the concept of intervention. The second was the history of Russian-Syrian relations. The third was Russia's position from the Syrian crisis. The study revealed the interpretation of some analysts of the Russian position in support of Syria's economic interests and arms sales to Syria, which is one of the most important vital interests between Syria and Russia. Arms purchases from Russia amounted to approximately one billion and one hundred million dollars according to the 2010 statistics. The study reached an important result which is: Syria represents great importance to Russia in the political, economic and military fields, as well as being one of the most important allies in Middle East region. Othman and Mohammed (2015), investigated the effects of Syrian-Russian bilateral agreements on the Syrian foreign trade in general and the Syrian-Russian trade in particular, based on analyzing the Syrian-Russian trade balance, to show the role of these agreements on the volume of this balance. The study assumed in its Hypothesis: "The bilateral agreements play a positive role in developing Syrian-Russian relationships. The study followed to prove its hypothesis the descriptive approach to the narrative of facts, and then collect data for analysis based on signed bilateral agreements, as well as foreign trade figures and statistics under these agreements. Then study identified the weaknesses in the trade relations between the two countries, as well as strengths with a view to upgrading and strengthening Syrian foreign trade, which will positively affects the various aspects of life. The previous study reached important results, the most important of them are: The lack of bilateral agreements in the field of foreign trade between the two countries. The bilateral trade agreements between them have not yet reached the level of other fields of cooperation. Therefore, it recommended the promotion of bilateral agreements and their development in the field of foreign trade. Yu, (2016) talked about: the historical development of the RussianChinese relations. It also presented and analyzed the agreements signed between the two sides. But the focus of her attention was to talk about the recent meeting between the Russian and Chinese presidents at the end of 2015 and its role in deepening the bilateral economic relations between the two countries against the sanctions imposed by the West. She also focused on the economic issues that occupied the agenda of recent meetings between the two sides, which focused on areas of cooperation in finance, investment, energy, science and technology manufacturing. The study also dealt with a political aspect, represented in the position of both countries towards the Syrian crisis. The most related and important result of the study was: The Federal Republic of Russia came as a direct supporter of Syria in its battle against terrorism. China was more moderate because of its close and strong relations with all the international parties that have different positions on the Syrian crisis. Borah, (2017) main focus was to explore and examine Syria's increasing closeness with Russia at the backdrop of the Syrian domestic crisis. According to Borah study, in 2000s closer relations were witnessed between them while Syria was facing increasing international isolation due to a variety of factors. The study aimed to understand deepening of relations between Syria and Russia taking into account the political, military and economic dimensions. Result related to economic dimension was: Syria's engagement with Russian companies in different areas has increased over the years. Bagan, (2017) aimed to analyze the determinants and goals of Russia's foreign policy towards Syria and attempted to answer the question of the causes and interests that underlie Russia's involvement there on the side Syrian government. According to Bagan: "Syria is not the main priority of Russia's foreign policy, however, it remains the crucial partner in the Middle East. Nevertheless, Middle Eastern countries, are not as important economic partners of Russia as European or the Far Eastern countries. Instability in the Middle East and rather pessimistic prospects are not promising for improving economic cooperation and trade with the region. The situation in the mid-term perspective is unlikely to change". 


\section{Syrian-Russian Bilateral Trade Agreements:-} Agreement by Syrian-Russian bilateral committee in 2004:-

The Russian-Arab Businessmen's Council and the Federation of Syrian Chambers of Commerce signed an agreement in 2004, called the Russian-Syrian bilateral committee, before the two countries signed a joint declaration on the further deepening of friendly relations and cooperation between the two countries.

Agreement on mutual cooperation and assistance in customs matters between Syria and Russia and other trade agreements in 2005:-

The customs cooperation agreement came after the Syrian president's visit to Russia in 2005, where a customs agreement was signed with the Government of the Russian Federation for mutual administrative cooperation and assistance in the customs matters contained in Legislative Decree 3 of 2015, including technical and administrative cooperation, information exchange, controlled delivery, investigations and information secrecy. The Customs Agreement, at the beginning of its text, presented the main objectives of the Customs Agreement (Syrian Customs: Conventions):

1. Violations of customs legislation are unfair to the economic, social and cultural interests of both countries.

2. Importance of providing an assessment of customs duties and taxes and other expenses in respect of the import and export of goods, in addition to the appropriate implementation of the provisions of banning, restricting the import and export of goods.

3. The necessity of international cooperation in matters related to the application of customs legislation.

4. Efforts to prevent customs violations, could have a more effective impact through cooperation between customs departments of both countries.

5. Reduce illegal trafficking in narcotic drugs and substances, affecting the mind, which pose a danger to public health and society.

Syrian-Russian trade agreement for the exchange of heavy oil with refined oil in 2012:-

On 9-1-2012, four agreements were signed on cooperation in the field of gas and oil and the development of economic, commercial and scientific relations as well as Russia's pledge to support Syria militarily and to stand by its side politically (Maleky, 2015). In Moscow in 2012, Syria signed a bilateral trade agreement with Russia to export heavy oil to Russia for refined oil. The agreement includes Syria's delivery of crude oil to Russia, which is estimated to produce 200,000 barrels of oil per day, in exchange for gasoline and fuel. The agreement is a swap agreement. (Oil \& Gas Technology, 2012).

Syrian-Russian memorandum of understanding on the economic customs framework in 2016:-

On May 25, 2016, the Syrian-Russian Joint Committee, which held two posts: Deputy Prime Minister of the Russian Federation for Economic Affairs and Chairman of the Syrian-Russian High Joint Committee Dimitri Rogozin and former Syrian Prime Minister Wael Al-Halaki, reached -during their meeting in the Council of Ministers- to issue a memorandum of understanding on the areas of cooperation in the economic customs framework (Al-furat, 2017), especially in the fields of energy and customs. Signed by the Syrian side: Minister Assistant of Economy and Foreign Trade: Hayyan Salman, and by the Russian side: Russian ambassador in Damascus: The meeting dealt with issues related to the mechanisms of signing a customs agreement. During the meeting, several subcommittees were formed to study all the issues, namely the Foreign Affairs Committee and the Committee on Financial, Banking and Economic Affairs. These committees held several bilateral meetings and presented their proposals, mechanisms and draft agreements to the Higher Committee for approval, in order to enhance the prospects of bilateral cooperation between the two countries (Syrian Ministry of Finance website).

Memorandum of Understanding for Establishing a permanent exhibition of Syrian Export-Products and Syrian House of Businessmen in Russia in 2016:-

A memorandum of understanding was signed to establish a permanent exhibition for Syrian products destined for export to Russia between Syrian Export and Product Support and Development Authority as a first team, represented by the director of the Authority: Mahdi Al-Dali and the Russian company Adyg Yurak. The importance of establishing this exhibition would be marketing of Syrian products. The provisions of the memorandum as followings (Syrian Export and Product Support and Development Authority, 2016).

The opening of the main headquarters of the Syrian House will be within a month from the date of confirmation of the memorandum, where the Russian company will allocate a suitable place with an area of not less than 2000 square meters for the establishment of the headquarters of the Syrian House in the city of Maykob in the Adygeya 
Republic within the Russian Federation, and properly equipped with basic services and electricity, water and communications infrastructure, as well as the establishment of other branches of the Syrian House within four months, the first will be in other regions such as: Smara - Novorossiysk - Moscow - San Petersburg - Rostov and other cities, where necessary, as well as work on opening branches in the Republic Belarus.

The Russian company provides the necessary assistance to work in the Syrian House in the field of trade and economic information, study the Russian market and exchange of export offers that will develop trade cooperation and achieve economic, commercial and industrial integration between the two countries, and facilitate the procedures of entering Syrian goods and products through shipping, and providing the necessary facilities to obtain entry visas for traders, industrialists, businessmen and workers, and mediate with the relevant Russian authorities to facilitate the management and operation of the Syrian house.

The obligations of the Syrian Export and Product Support and Development Authority are: to supervise the work of the Syrian House, to coordinate with those necessary to provide the Syrian house management staff, to provide necessary assistance in the field of trade and economic information, to study the Syrian market and to exchange export offers, To facilitate and simplify trade procedures. According to the memorandum of understanding, the establishment of the Syrian house helps in:

1. Supporting the signing of deals between Syrian and Russian traders, since the Russian market with its geographical area and economic potential is able to absorb all Syrian products, but in light of the lack of information, there was no good marketing of Syrian products, for that, the Syrian House will be a channel for direct sales to the Russian consumers.

2. Developing the appropriate means and formulas to: stimulate trade exchange, improve the quality of products, increase their efficiency and competitiveness, encourage export-oriented investment and develop economic, commercial and industrial cooperation and integration between the two countries in all possible fields.

\section{Other Syrian-Russian Bilateral Trade Agreements- in brief:-}

1. Agreement on the International Carriage by Road: Approved by the Syrian side in Legislative Decree No. 22 dated 6-4-2005.

2. Memorandum of the expanded meeting of the Syrian-Russian Business Council: and the signing of the joint Syrian-Russian statement on deepening the friendly relations and cooperation between the two countries.

3. Memorandum of Understanding in the Field of Standards and Metrology: Signed on 16-3-2006.

4. Memorandum of Understanding for Joint Cooperation: Between the Syrian-Russian Businessmen Council and the Federation of Chambers of Commerce, Agriculture, Tourism, Syrian Maritime Navigation, 26-4-2007.

5. Agreement on cooperation in combating illicit traffic in narcotic drugs: psychotropic substances, dated 3-9-2007 (Issa, 2016).

6. Agreement on cooperation in the field of air transport for 2010: This agreement came after the visit of President Medvedev to Damascus in 2010 (Website of the Syrian electronic steps, 2012).

\section{Russia as an Export Partner of Syria - Analytical Study-:- \\ Basic statistical measures: - \\ Arithmetic Mean, Standard Deviation and Coefficient of Variation:-}

The means of the foreign trade time series variables was calculated to measure the central tendency of these series, while the standard deviation (Stdev) was computed to determine the degree of dispersion of the data from their means. The coefficient of difference (CV) describes the variables from both sides, e.g.: export volatility, this ratio is calculated by dividing the standard deviation on the arithmetic mean, relationships (1), (2) and (3):

$$
\begin{gathered}
\text { Mean }=\bar{x}=\frac{\sum_{i=1}^{n} x_{i}}{n} \\
\text { Stdev }=\sqrt{\frac{\sum(x-\bar{x})^{2}}{n}} \\
C V=\frac{\text { Stdev }}{\text { Mean }}
\end{gathered}
$$

Linear correlation coefficient Pearson:-

Linear correlation coefficient Pearson (R) was used to measure the degree of correlation between the variables used and GDP at market prices. The coefficient of correlation between variables $\mathrm{x}$ and $\mathrm{y}$ is given in relation (4): 


$$
R=\frac{n\left(\sum x y\right)-\left(\sum x\right)\left(\sum y\right)}{\sqrt{n \sum x^{2}-\left(\sum x\right)^{2}} \sqrt{n \sum y^{2}-\left(\sum y\right)^{2}}}
$$

\section{Coefficient of regression equation $\left(b_{1}\right)$ :-}

The Coefficient of regression equation or Slope $\left(\boldsymbol{b}_{1}\right)$ has been used to measure the relationship between independent and dependent variables, for example: measuring the linear relationship between exports to Russia and GDP, in other words determining the response in degree and direction for Syria's exports to Russia as change is made in Syria's GDP. (5) (Al-Suwaidi, 2012):

$$
b_{1}=\frac{n \sum X_{i} Y_{i}-\sum X_{i} \sum Y_{i}}{n \sum X_{i}^{2}-\left(\sum X_{i}\right)^{2}}
$$

Annual Growth Rate $\left(\overline{G R_{i}}\right)$ :-

The annual growth $\left(\overline{\boldsymbol{G} \boldsymbol{R}_{\boldsymbol{i}}}\right)$ rate has been used to compute the evolution of the time series variables, both in terms of values and ratios. The annual growth rate is equal to the subtract value of the variable in the year (i) from its value in the previous year $\left(i_{-1}\right)$ divided by the value of the variable in the year $\left(i_{-1}\right)$, and its average value equals to: sum up of annual growth rates of the series over the number of years divided by number of years minus one. Relationships (6) and (7):

$$
\begin{aligned}
G R_{i} & =\frac{\left(x_{i}-x_{i-1}\right)}{x_{i-1}} \\
\overline{G R} & =\frac{\sum_{i=1}^{n} G R_{i}}{n-1}
\end{aligned}
$$

\section{Compound annual growth rate (CGR):-}

The compound annual growth rate has been used to create a constant annual growth rate that develops the value of the variable in the first year of the series, reaching its value in the last year. It is more reliable than the annual growth rate because it ignores abnormal values in the middle of the series, which may lead to misleading results, When calculating the average annual growth rate as in the relationship (7). The Composite Growth Rate (CGR) is calculated by relationship (8) (Anson et al., 2010, p.489):

$$
\mathrm{CGR}=\left(\frac{\text { Value }_{t n}}{\text { Value }_{t 0}}\right)^{\frac{1}{t n-t 0}}-1
$$

\begin{tabular}{|c|c|c|c|}
\hline Symbol & Variable & Symbol & Variable \\
\hline Max & Maximum Value & GDP & Gross domestic product \\
\hline Min & Minimum Value & GDP $_{-1}$ & Slowdown GDP \\
\hline Mean & Arithmetic mean & $\mathbf{X}$ & Export \\
\hline Stdev & standard deviation & $\mathbf{M}$ & Import \\
\hline Mean Ratio & The arithmetic mean of the ratios & $\mathrm{X}-\mathrm{M}$ & Net trade balance \\
\hline GR & Annual growth rate & $\mathbf{X}_{\text {Rus }}$ & Exports to Russia \\
\hline Ratio GR & Annual growth rate of the ratios & $\mathbf{M}_{\text {Rus }}$ & Imports from Russia \\
\hline CGR & Compound growth rate & & \\
\hline$b_{1}$ & Slope & & \\
\hline $\mathbf{R}$ & Coefficient of correlation & & \\
\hline Rank & Rank & & \\
\hline
\end{tabular}

Where: "Value $e_{t n}$ ":value in the last year of the time series, "Value ${ }_{t 0}$ ": value in the first year of the series. symbols used in this study are presented in Table 1:

Table 1:-Symbols used in the study:

Syrian export trends and the position of Russia among export partners of Syria:-

It is essential to measure the depth of trade relations with Russia, by conducting a comparative study of the volume of trade with it compared to other countries. For a long period of time, foreign trade data were collected with 17 countries, and statistical measures wear calculated, Table 2 showing that:

Table 2:-Analysis Results of Syrian Exports Trends by Main Countries:

\begin{tabular}{|l|l|l|l|l|l|l|l|l|l|}
\hline Variable & Italy & Iran & USA & India & Germany & Iraq & China & KSA & Jordan \\
\hline Rank & 1 & 17 & 10 & 12 & 7 & 2 & 15 & 4 & 9 \\
\hline MAX & 126396 & 1827 & 18479 & 8926 & 75984 & 125711 & 5175 & 56596 & 24626 \\
\hline Year & 2007 & 2007 & 2010 & 2016 & 2008 & 2009 & 2011 & 2007 & 2007 \\
\hline
\end{tabular}




\begin{tabular}{|l|l|l|l|l|l|l|l|l|l|}
\hline MIN & 2183 & 0 & 0 & 47 & 0 & 0 & 1 & 2389 & 438 \\
\hline Year & 2013 & 2012 & 2013 & 1997 & 2014 & 1998 & 2000 & 1997 & 1999 \\
\hline MEAN & 48207 & 406 & 6390 & 1197 & 14760 & 34941 & 978 & 23017 & 10976 \\
\hline STDEV & 40732 & 511 & 6421 & 2056 & 24566 & 42171 & 1420 & 14764 & 7898 \\
\hline CV & 0.64 & 0.84 & 1.26 & 1.00 & 1.72 & 1.66 & 1.21 & 1.45 & 0.64 \\
\hline R(X, GDP) & -0.423 & 0.355 & -0.070 & 0.808 & 0.193 & 0.441 & 0.270 & 0.473 & 0.658 \\
\hline b1(X, GDP) & -0.01254 & 0.00013 & -0.00033 & 0.00121 & 0.00345 & 0.01355 & 0.00028 & 0.00508 & 0.00379 \\
\hline b1(X,GDP.1) & -0.01984 & 0.00012 & -0.00088 & 0.00137 & 0.00383 & 0.01590 & 0.00029 & 0.00498 & 0.00435 \\
\hline Variable & Egypt & Lebanon & France & Romania & Belgium & Russia & Turkey & Bulgaria & \\
\hline Rank & 8 & 5 & 3 & 16 & 14 & 13 & 6 & 11 & \\
\hline MAX & 34011 & 62179 & 61279 & 4374 & 3472 & 2307 & 29593 & 11231 & \\
\hline Year & 2008 & 2008 & 2007 & 2015 & 2008 & 2006 & 2008 & 2015 & \\
\hline MIN & 329 & 0 & 0 & 142 & 0 & 404 & 3348 & 0 & \\
\hline Year & 1998 & 2012 & 2015 & 1999 & 2012 & 2004 & 1998 & 2016 & \\
\hline MEAN & 11395 & 18060 & 26088 & 753 & 1032 & 1061 & 16400 & 1933 & \\
\hline STDEV & 9555 & 17296 & 21079 & 1026 & 926 & 612 & 8607 & 2866 & \\
\hline CV & 0.84 & 0.96 & 0.81 & 1.36 & 0.90 & 0.58 & 0.52 & 1.48 & \\
\hline R(X, GDP) & 0.672 & 0.723 & -0.473 & 0.363 & -0.014 & 0.289 & 0.272 & 0.536 & \\
\hline b1(X, GDP) & 0.00468 & 0.00910 & -0.00727 & 0.00027 & -0.00001 & 0.00013 & 0.00170 & 0.00112 & \\
\hline b1(X, GDP.1) & 0.00532 & 0.00954 & -0.01123 & 0.00024 & -0.00007 & 0.00017 & 0.00092 & 0.00128 & \\
\hline
\end{tabular}

The Position of Russia as an export partner in ranking of the most important export partners: Italy ranked first in terms of Syrian exports with a Mean value of (48207) million Syrian pounds for the series [2016-1997], followed by Iraq, France and Saudi Arabia. While Russia achieved a Low rank $13^{\text {th }}$ out 17 countries are the most important export partners of Syria.

The position of Russia as an export partner in the boom years: series part [2000-2010], where the period of Syrian export prosperity, and the period of signing the largest number of trade agreements with Russia, the most important of them are:

1. Agreement of the Russian-Syrian bilateral committee in 2004.

2. Customs Agreement in 2005.

3. Memorandum of the Expanded Syrian-Russian Business Council Meeting in 2005.

4. Memorandum of Understanding in the field of standards and standards in 2006.

5. Memorandum of Understanding for Joint Cooperation in 2007.

6. Agreement on cooperation in the field of air transport in 2010.

Syrian exports to the following countries achieved the greatest values: Italy, France, Saudi Arabia, Iraq, while Russia ranked 12th in 2006. Based on the above, Russia was not an export partner during Syrian boom period.

The position of Russia as an export partner in the years of economic regression: series part [2011-2016], where the period of the Syrian crisis, as it is the period of signing three trade agreements with the Russian side, are:

1. Syrian-Russian trade agreement for the exchange of heavy oil with refined oil in 2012.

2. Syrian - Russian memorandum of understanding on the economic customs framework in 2016.

3. Memorandum of Understanding for Establishing a permanent exhibition of Syrian Export-Products and Syrian House of Businessmen in Russia in 2016.

The countries that strengthened their partnership with Syria during the crisis years are: the regional countries: Lebanon, Iraq, Saudi Arabia, Turkey, while Russia ranked $13^{\text {th }}$ in 2016. According to the above, Russia was not an export partner during the regression of Syrian Economy.

Determining Russia's position as an export partner in the volatility index (CV): Syrian exports to the following countries are the most volatile: Germany (CV: 1.72), Iraq (CV: 1.66), Bulgaria (CV: 1.48), while The most stable Syrian exports were for the following countries: Turkey (CV: 0.52), Russian Federation (CV: 0.58), Italy and Jordan (CV: 0.64).

Determining Russia's position as an export partner through the slope of regression equation $\left(b_{1}\right)$ : The country with the largest positive value of the slope of the Syrian export regression equation to GDP $_{-1}$ is considered an important 
export partner in terms of the direction of the future relationship, as any increase in gross domestic product, a large proportion of it would be transferred to this partner. The ranking of the most important countries according to this criterion are Arab countries: Iraq ( $b 1=0.0159 ; \mathrm{R}=0.441$ ), Lebanon ( $\mathrm{b} 1=0.00954 ; \mathrm{R}=0.723$ ), Saudi Arabia (b1: 0.00498; $\mathrm{R}=0.473$ ) ; Jordan ( $\mathrm{b} 1=0.00435 ; \mathrm{R}=0.658$ ). But how Italy came out of the rank according to this criterion, although the ranking is the first according to the Mean value of exports. The reason is the downward trend of exports to Italy after 2011, because of its commitment to the US sanctions on Syria, And therefore it could be judged that this criterion defines future partners.

For Russia, the slope and the correlation coefficient (b1: 0.00017; R: 0.289) were weak, indicating a slight future improvement in Syrian exports to Russia. The previous analysis could be supported by the graph analysis, (Fig 1) shows the change in Syria's most important export partners, and the position of Russia between them during the period [1997-2016]. In 1997, the top three ranked countries were: Italy, France, Turkey. Russia ranked sixth was relatively advanced. In 2006, previous countries maintained their positions while Russia fell to $12^{\text {th }}$ place. In 2016, the ranking of the first countries changed to Lebanon, Iraq and Saudi Arabia, while Russia advanced to $10^{\text {th }}$ place, which is still lagging behind. On average, Syria's export partners are: Italy, Iraq, France, while Russia is in the 13th place.

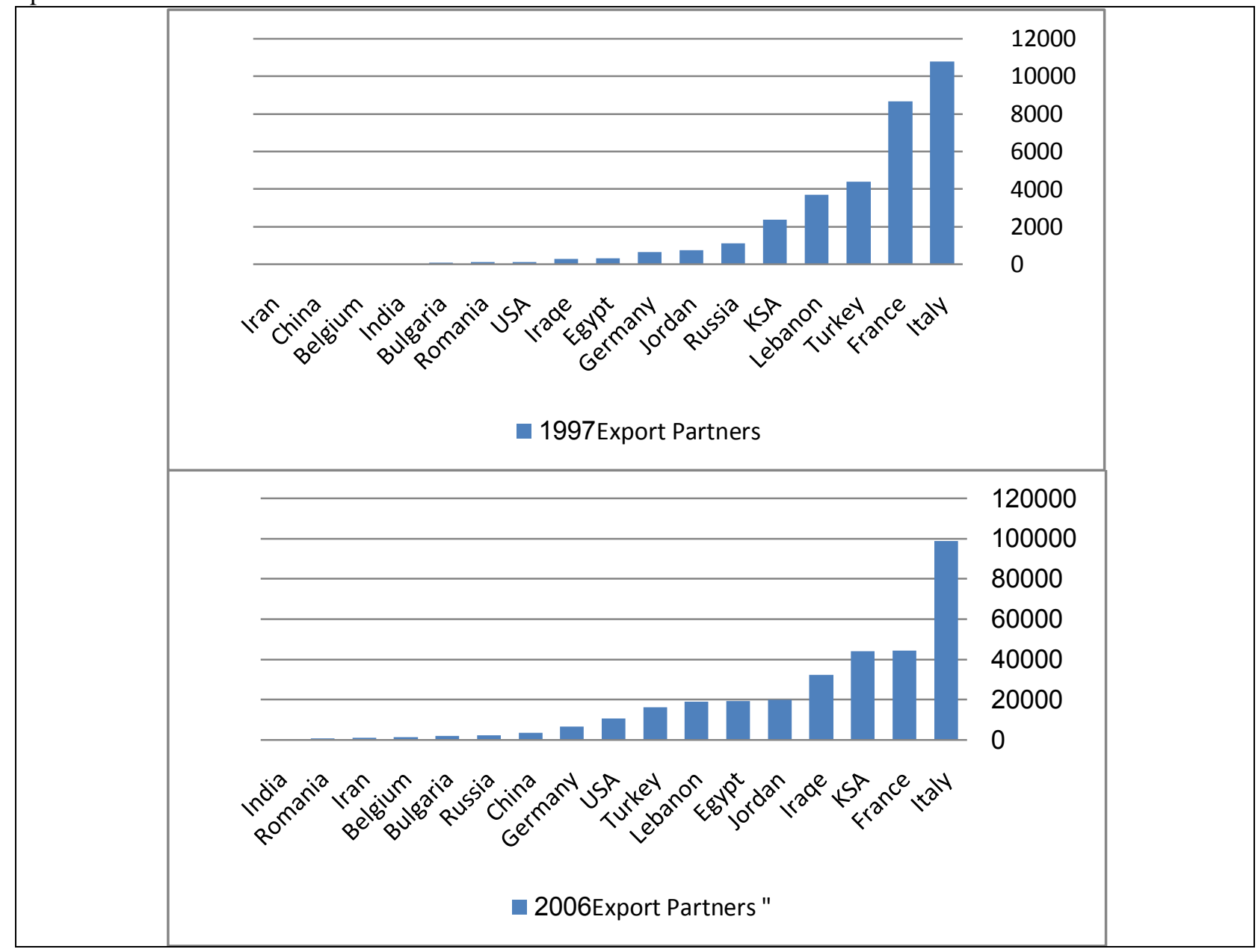




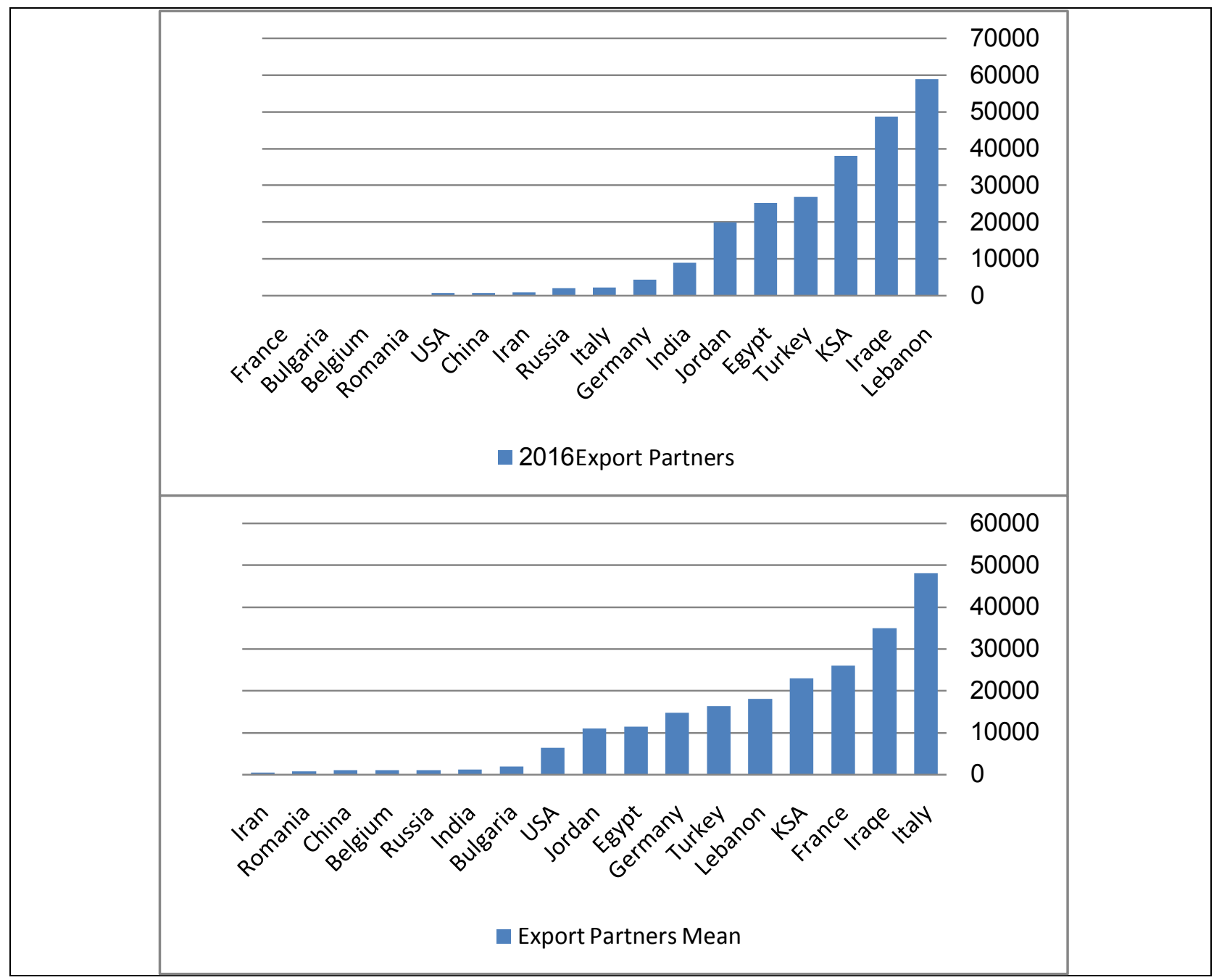

Fig 1:-Ranking of countries according to Syrian exports.

The ranking of the countries could be redrawn according to the net trade balance, to determine countries in which the trade balance goes in favor of Syria,. Table 3 shows this, where, X: Mean export value of the [1997-2016] series by country, M: Mean value of imports of the [1997-2016] series by country, X-M: net trade balance, positive value indicates that the balance is profitable to Syria. Rank: indicates the order of the trading partner.

Table 3:-Analysis results of the trading partners of Syria:

\begin{tabular}{|l|l|l|l|l|l|l|}
\hline Country & $\mathbf{X}$ & $\mathbf{M}$ & $\mathbf{X}-\mathbf{M}$ & $\mathbf{X}$ Rank & M Rank & $(\mathbf{X - M})$ Rank \\
\hline Iraq & 34941.0 & 2855.3 & 32085.7 & 2 & 17 & 1 \\
\hline Italy & 48206.9 & 28666.5 & 19540.4 & 1 & 3 & 2 \\
\hline France & 26087.5 & 9833.5 & 16254.1 & 3 & 11 & 3 \\
\hline Jordan & 10976.5 & 9000.7 & 1975.8 & 9 & 13 & 4 \\
\hline Germany & 14759.8 & 13920.9 & 838.9 & 7 & 9 & 5 \\
\hline Saudi & 23016.6 & 22531.5 & 485.1 & 4 & 6 & 6 \\
\hline Bulgaria & 1932.9 & 4982.1 & -3049.2 & 11 & 16 & 7 \\
\hline Lebanon & 18059.8 & 21676.6 & -3616.8 & 5 & 7 & 8 \\
\hline USA & 6390.4 & 10621.3 & -4231.0 & 10 & 10 & 9 \\
\hline Belgium & 1032.0 & 5459.9 & -4427.9 & 14 & 15 & 10 \\
\hline
\end{tabular}




\begin{tabular}{|l|l|l|l|l|l|l|}
\hline Iran & 405.7 & 7920.8 & -7515.1 & 17 & 14 & 11 \\
\hline Romania & 753.1 & 9021.5 & -8268.3 & 16 & 12 & 12 \\
\hline Turkey & 16400.2 & 28522.9 & -12122.7 & 6 & 4 & 13 \\
\hline Egypt & 11395.5 & 24940.8 & -13545.3 & 8 & 5 & 14 \\
\hline India & 1197.4 & 15725.7 & -14528.3 & 12 & 8 & 15 \\
\hline Russia & 1061.3 & 42020.7 & -40959.4 & 13 & 2 & 16 \\
\hline China & 978.3 & 48614.7 & -47636.4 & 15 & 1 & 17 \\
\hline
\end{tabular}

Syria has a profitable trade balance during the period [1997-2016] with six countries out of 17 trade partners, which are: Iraq, Italy, France, Jordan, Germany and Saudi. As for the remaining 11 countries, the balance of trade has negative signs, denoting that it is not in Syria's favor, that includes Russia, which takes the rank $\left(\mathrm{X}-\mathrm{M}_{\mathrm{Rank}}=16\right)$.

\section{Linear Regression Model of Syrian Export to Russia on GDP :-}

Linear Regression Model of Syrian Export to Russia on GDP was conducted for the series [1997-2016], to determine the direction of Syrian export to Russia related to the improvement in Syrian GDP. Table 4 shows the model of the regression of Syrian exports to Russia on GDP:

Table 4:-Results of the of Syrian exports to Russia Regression on GDP:

\section{Dependent Variable: X-Russia}

\begin{tabular}{|l|l|l|l|l|}
\hline Variable & Coefficient & Std. Error & t-Statistic & Prob. \\
\hline C & 780.1495 & 257.1559 & 3.033761 & 0.0071 \\
\hline GDP & 0.000129 & 0.000101 & 1.282749 & $\mathbf{0 . 2 1 5 9}$ \\
\hline R-squared & 0.083757 & Mean dependent var & 1061.300 \\
\hline Adjusted R-squared & 0.032855 & S.D. dependent var & 611.6310 \\
\hline S.E. of regression & 601.4996 & Akaike info criterion & 15.73137 \\
\hline Sum squared resid & 6512432 & Schwarz criterion & 15.83094 \\
\hline Log likelihood & -155.3137 & Hannan-Quinn criter. & 15.75081 \\
\hline F-statistic & 1.645444 & Durbin-Watson stat & 1.640486 \\
\hline Prob(F-statistic) & 0.215853 & $\mathrm{R}=0.289$ & \\
\hline
\end{tabular}

From the table above: Intercept $(C=780.15)$, slope of the regression equation $(b=0.000129)$, but the probability value $(a=0.2159>0.05)$, denoting that the relationship is not significant, and the linear regression model does not represent this relationship. Also, the decline in the value of the coefficient of determination $\left(R^{2}=0.0837\right)$, i.e., the linear regression equation model does not fit the distribution of Syrian exports to Russia on the GDP. The Reasons led to this result maybe: The direction of Syrian Exports as GDP rise is not Russia. (Fig 2) shows no obvious trend of Syrian exports to Russia during the period [1997-2016].

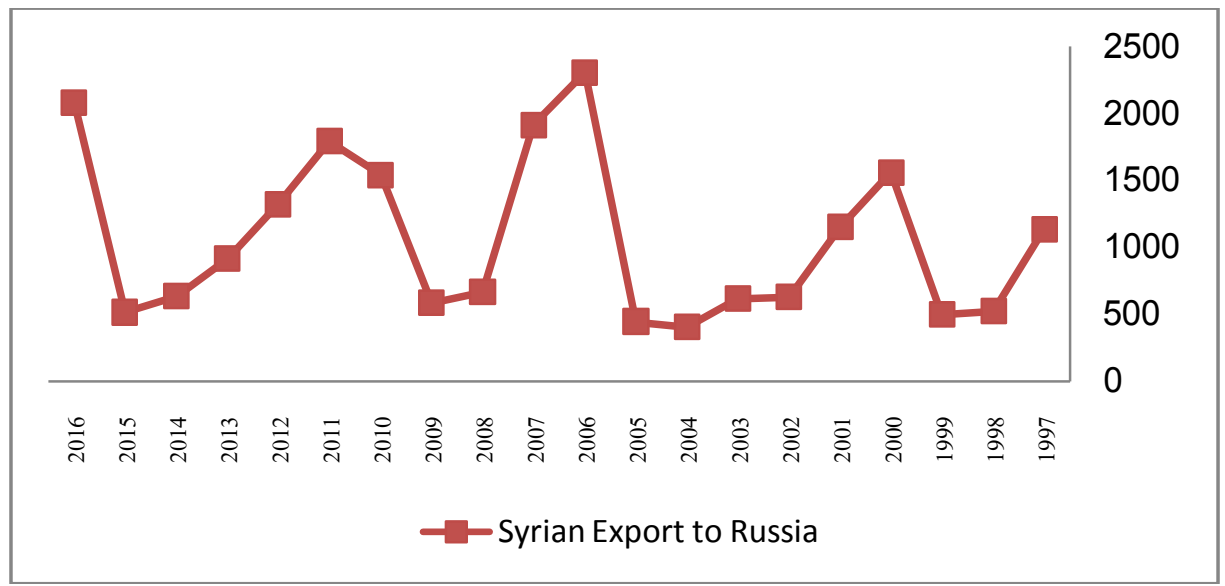

Fig 2:-Development of Syrian Exports to Russia. 
A Comparative Analysis of Syrian exports structure (Overall and to Russia) according to sections and chapters of the International Standard Classification of Foreign Trade Amendment (3):-

The objective of this analysis is to determine the degree of convergence between the structure of Syrian Export in accordance with the international classification (3) and its structure with Russia according to the classification itself. The availability of statistics limits the analysis to 2010, the year where study was able to collect its data according to the double classification criterion (Criterion 1: International Standard Classification (3), Criterion 2: by countries), Table 5 Illustrate the results, and (Fig 3), explains the terms of trade between the two countries:

Table 5:-A Comparative Analysis Results of Syrian exports structure (Total and to Russia) according to International Standard Classification (3) in 2010:

\begin{tabular}{|c|c|c|c|c|c|c|c|}
\hline Item & $\mathbf{x}_{\text {iRus }}$ & $\mathbf{x}_{\mathbf{i}}$ & $\begin{array}{l}\mathbf{x}_{\text {iRus }+} \\
\mathbf{m}_{\text {iRus }}\end{array}$ & $\mathbf{x}_{\mathrm{i}} / \mathbf{X}$ & $\begin{array}{l}\mathbf{X}_{\text {iRus }} / \\
\mathbf{X}_{\text {Rus }}\end{array}$ & $\begin{array}{l}\mathbf{x}_{\text {i-Rus }} l \\
\mathbf{x}_{\text {iRus }}+\mathbf{m}_{\text {iRus }}\end{array}$ & $\begin{array}{l}\mathbf{x}_{\mathbf{i}-\text { Rus }} / \\
\mathbf{x}_{\mathbf{i}}\end{array}$ \\
\hline Food and live animals & 448.9 & 99526 & 5724.1 & 18.96 & 29.13 & 7.84 & 0.45 \\
\hline Beverages and tobacco & 0.0 & 5301 & 18.1 & 1.01 & 0.00 & 0.00 & 0.00 \\
\hline Raw materials other than fuel & 10.7 & 20089 & 2985.9 & 3.83 & 0.70 & 0.36 & 0.05 \\
\hline Mineral fuels & 0.0 & 26193 & 36617. & 49.89 & 0.00 & 0.00 & 0.00 \\
\hline Animal oils and greases & 1.6 & $\overline{4317}$ & 327.3 & 0.82 & 0.11 & 0.5 & 0.04 \\
\hline Chemicals and their products & 123.0 & 32518 & 1577.4 & 6.19 & 7.98 & 7.80 & 0.38 \\
\hline Manufactured goods & 686.4 & 52724 & 4841.1 & 10.04 & 44.54 & 14.18 & 1.30 \\
\hline $\begin{array}{lll}\text { Machinery } & \text { and } & \text { transport }\end{array}$ & 62.8 & 11288 & 509.4 & 2.15 & 4.07 & 12.32 & 0.56 \\
\hline Miscellaneous Crafts & 207.7 & 37368 & 223.4 & 7.12 & 13.48 & 92.99 & 0.56 \\
\hline Total & 1541. & 52506 & 52824. & 100.0 & 100.00 & 2.92 & 0.29 \\
\hline
\end{tabular}

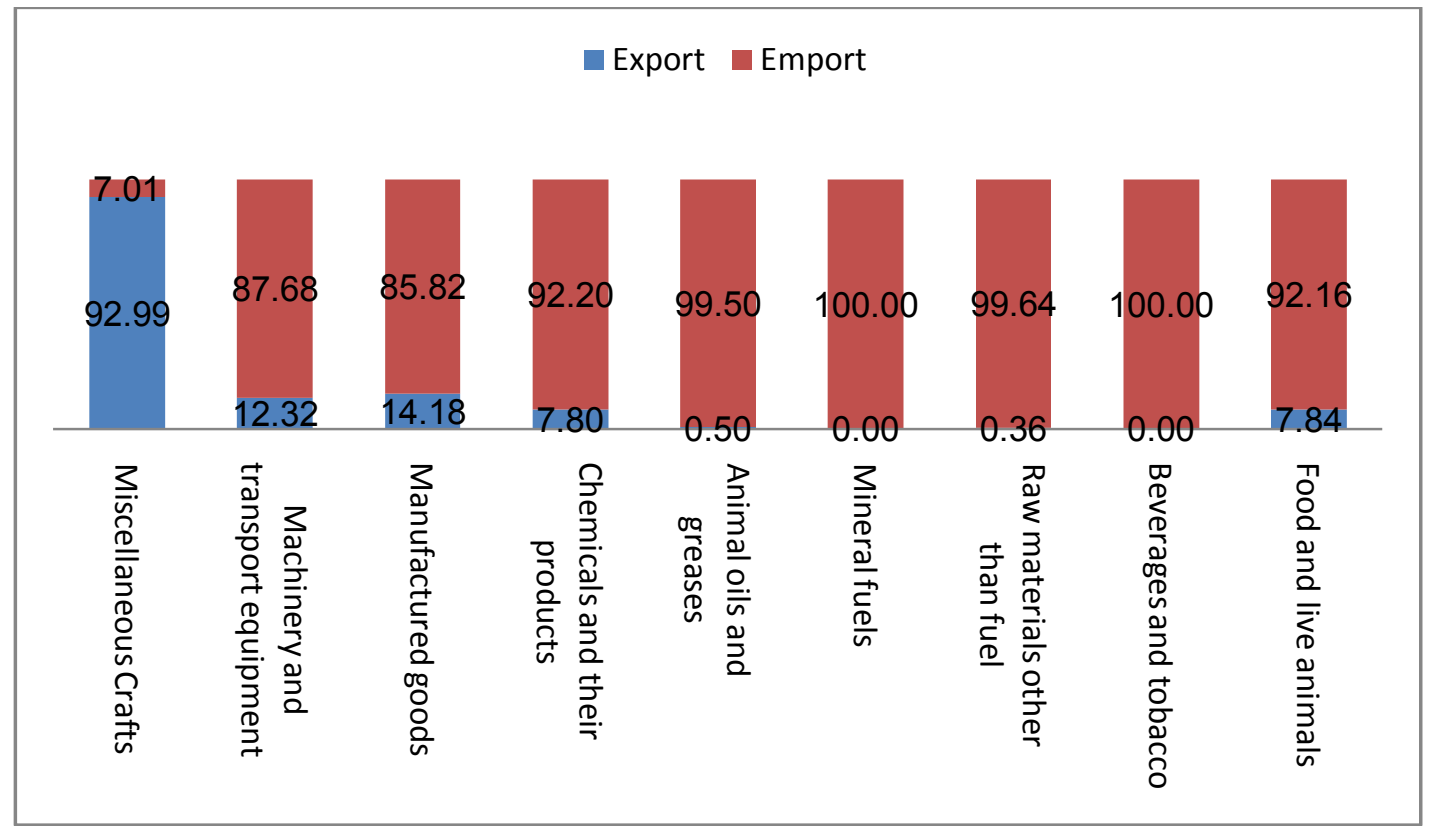

Fig 3:-Trade ratios between Syria and Russia for 2010.

According to table 5, and (Fig 3), the following results were obtained:

Machinery and transport equipment:

The Ratio of Syrian exports to Russia of this commodity to total export to Russia in 2010 were $\left(\frac{x_{i R u s i}}{X_{R u s}}=4.07 \%\right)$ vs. $\left(\frac{x_{i}}{X}=2.15 \%\right)$ The ratio of total exports of this commodity to total exports. This shows a slight increase in Russia's 
relative share of exports of this commodity, but the percentages remain weak, not of relative importance for Syria. The ratio of exports to Russia of this commodity to the total trade between the two countries $\left(\frac{x_{i R u s}}{x_{i R u s}+m_{i R u s}}=\right.$ $12.32 \%$ ) was a sign of the superiority of imports on exports of these commodity. Finally, the exports of this commodity to Russia compared to the total exports of the same commodity $\left(\frac{x_{i R u s i}}{x_{i}}=0.56 \%\right)$. From the previews results, we can conclude that: The relative importance of Syrian exports to Russia from this high value commodity is Low.

\section{Miscellaneous goods:}

Syrian exports to Russia of these commodities in 2010 were $\left(\frac{x_{i R u s i}}{X_{\text {Rus }}}=13.48 \%\right)$ vs. ( $\left.=\frac{x_{i}}{X}=7.12 \%\right)$, this shows a superiority to Russia, any way this ratio still Low. The ratio of Russian exports of these commodities to the total trade exchange between the two countries was $\left(\frac{x_{i R u s i}}{X_{R u s}+M_{R u s}}=92.99 \%\right)$, a sign of a superiority of export on import of this commodies. Finally, exports of these commodities to Russia compared to the total exports of the same commodities were weak $\left(\frac{x_{i R u s i}}{x_{i}}=0.56 \%\right)$. One inference could be reached from that is: The relative importance of this commodities for Syria is medium, but Russia is not the destination.

\section{Chemicals and related products:}

Syrian exports to Russia of these commodities in 2010 were $\left(=\frac{x_{i R u s i}}{X_{\text {Rus }}}=7.98 \%\right)$ vs. $\left(\frac{x_{i}}{X}=6.19 \%\right)$, these percentages are also weak. The proportion of exports to Russia from these goods to the total trade exchange between the two countries amounted to $\left(\frac{x_{i R u s i}}{X_{R u S}+M_{R u S}}=7.80 \%\right)$, evidence of the superiority of imports on exports of these commodities. Finally, exports of these commodities to Russia compared to the total exports of the same commodities were low $\left(\frac{x_{i R u s i}}{x_{i}}=0.38 \%\right)$. One important reference from above discussion: Although, the importance of these commodity in term of commercial value, but Syria failed to rise up its proportion in export, as well as Russia is not the destination.

\section{Mineral fuels, lubricants and similar materials:}

In 2010, there were no exports of fuel to Russia, while the overall standard was $\left(\frac{x_{i}}{X}=49.89 \%\right)$, i.e., Syria did not benefit from any signed agreement to export mineral fuel to Russia in this, when it was an oil exporter in that period. For imports, the share of this commodity is the highest $\left(\frac{m_{i R u s i}}{M_{R u s}}=71.40 \%\right)$, well above the overall average rate $\left(\frac{m_{i}}{M}=19.65 \%\right)$. This is evidence of Russia's use of signed economic agreements, to become the first supplier For fuel to Syria, where the proportion of imports of mineral fuels from Russia to total fuel imports $\left(\frac{m_{i R u s}}{m_{i}}=22.94 \%\right)$.

\section{Beverages and tobacco:}

Also in the study year, there were no exports of beverages and tobacco to Russia, while the overall index $\left(\frac{x_{i}}{X}=\right.$ $1.01 \%)$, i.e, the two ratios are weak, indicates that the industry is not seriously entering the export market. This is evidence that Syria did not benefit from the signed trade agreements to be a supplier of these commodity to Russia and rest of the world.

\section{Food and Live Animals:}

Food and live animals are considered to be relatively low prices. These commodities accounted for a relatively high share compared to the rest of Syria's exports to Russia: $\left(\frac{x_{i R u s i}}{X_{\text {Rus }}}=29.13 \%\right)$ vs. the overall index $\left(\frac{x_{i}}{X}=18.96 \%\right)$. However, the ratio ( $=\frac{x_{i R u s i}}{x_{i}}=0.45 \%$ ) indicates that Russia is not the only direction for these commodities, and that it constitutes a narrow market for it. The reason may far distance and its impact as it rise the cost of shipping.

\section{Oils, Fats and Animal and Plant Waxes:}

They are also commodities with low relative prices. These commodities accounted for a relatively low share $\left(\frac{x_{i R u} i}{X_{R u s}}=0.11 \%\right)$, as well as for the overall index $\left(\frac{x_{i}}{X}=0.82 \%\right)$. Indicating a weak production of these materials, that is, the impact of any bilateral agreements towards raising them will be limited impact. Also, the ratio $\frac{x_{i R u s i}}{x_{i}}=$ $0.45 \%$ ) indicates that Russia is not the only direction for these commodities. 


\section{Non-Edible Raw Materials Excluding Fuels:}

These commodities are included in the last trade list according to the relative price standard. As for Syria's exports to Russia, it was a low percentage $\left(\frac{x_{i R u s i}}{x_{R u s}}=0.70 \%\right)$. The overall index $\left(\frac{x_{i}}{X}=3.83 \%\right)$ indicates that external world did not attract enough Syrian exports of these commodities. Also, the ratio $\left(\frac{x_{i R u s i}}{x_{i}}=0.05 \%\right)$ indicates that Russia is not the only direction for these commodities. Table 5 could be graphically shown using the column chart to facilitate comparison, (Fig 4):

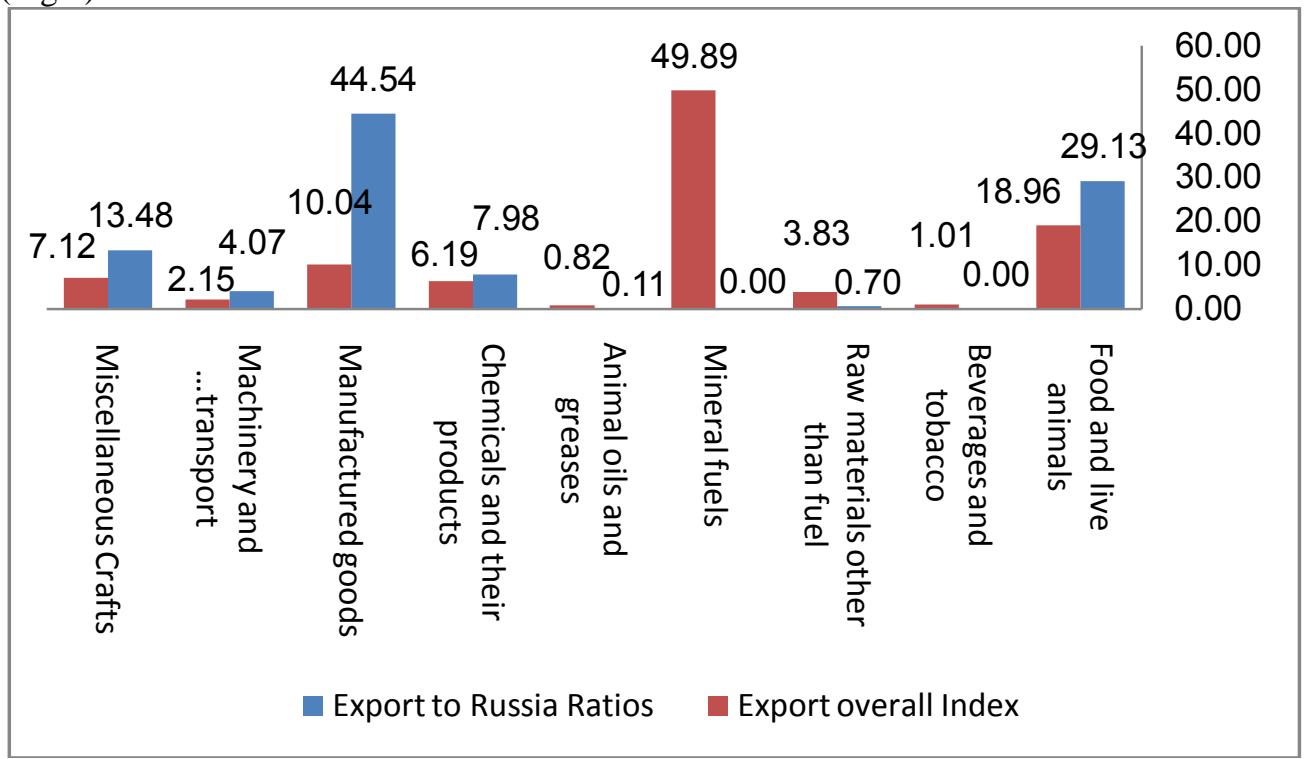

Fig 4:-Comparison of the Structure of Syrian Overall Exports and to Russia for 2010 (percentages).

\section{Results of the Study:-}

Based on the results of the analysis, the following conclusions could be drawn:

There are differences between the structure of the overall Syrian exports and with Russia in 2010 according to the International Classification (3), these differences takes two directions:

1. The share of exports of commodity $\left(\mathrm{x}_{\mathrm{i}}\right)$ to Russia out of total exports to it, is greater than the overall index, which is consistent with the arbitrage: $\left(\frac{x_{i R u s i}}{X_{\text {Rus }}}>\frac{x_{i}}{X}\right)$. Commodities that achieve this are: manufactured goods, food and live animals, means, Russia is an export partner of Syria in these commodities.

2. The share of exports of commodity $\left(\mathrm{x}_{\mathrm{i}}\right)$ to Russia out of total exports to it, is smaller than the overall index, which is consistent with the arbitrage: $\left(\frac{x_{i R u s i}}{X_{R u s}}<\frac{x_{i}}{X}\right)$. Commodities that achieve this are: Mineral fuels, which is a big paradox that the proportion of Syrian oil exports in 2010 about 50\%, Russia is not a partner. Russia is not an export partner at all, despite all agreements between the two countries in the oil field for previous periods. The second commodity is raw materials other than fuel, which are goods that do not require competitive advantages and Russia's share should have been greater than that of raw materials.

3. There is a convergence between the structure of the overall Syrian exports and with Russia in 2010 according to the International Classification (3), for the following commodities: Miscellaneous products, machinery and transport equipment, chemicals and products, oils and animal fats, raw materials other than fuel, beverages and tobacco. That lead to an important conclusion that: Syria-Russia bilateral trade agreements do not leave much impact on these categories of goods. From the previous analysis Study Hypothesis states that:" Syrian-Russian bilateral trade agreements have contributed to the improvement of Syrian exports in quantity and quality, so that Russia has become an export partner of Syria". Should be Rejected. We can support that by presenting the trade balance between Syria and Russia for 2010, (Fig 5). It could be seen that the net balance of trade in favor of Russia for all commodities except for miscellaneous products is in favor of Syria at a very small value. The balance sheet for mineral fuels reached -39617.9 billion S.P, and for food and live animals was -4826.2 billion S.P, followed by categories in term of import bill: machinery and transport equipment, manufactured goods, Raw materials other than fuel, and chemicals, while the rest are small and insignificant.

4. Based on monitoring the development of Syrian exports and, the time series [2016-1997] was divided into two periods, an economic boom period [1997-2010], a period of economic crisis and large inflation [2011-2016]. The 
result is: Russia is not an export partner of Syria according to the standard of the ranking of export partners: Not all bilateral economic agreements signed between the two countries, especially the trade ones led to improve the order of Russia as an export partner of Syria, both during the period of economic prosperity of Syria [19972010], which was signed 6 bilateral trade agreements with Russia, with Russia ranking $12^{\text {th }}$ out of 17 countries. Also, Russia is not an export partner of Syria in the period of the Syrian crisis [2011-2016], which was period of signing of trade agreements with Russia, where Russia still came in the ranking $12^{\text {th }}$ out of 17 countries.

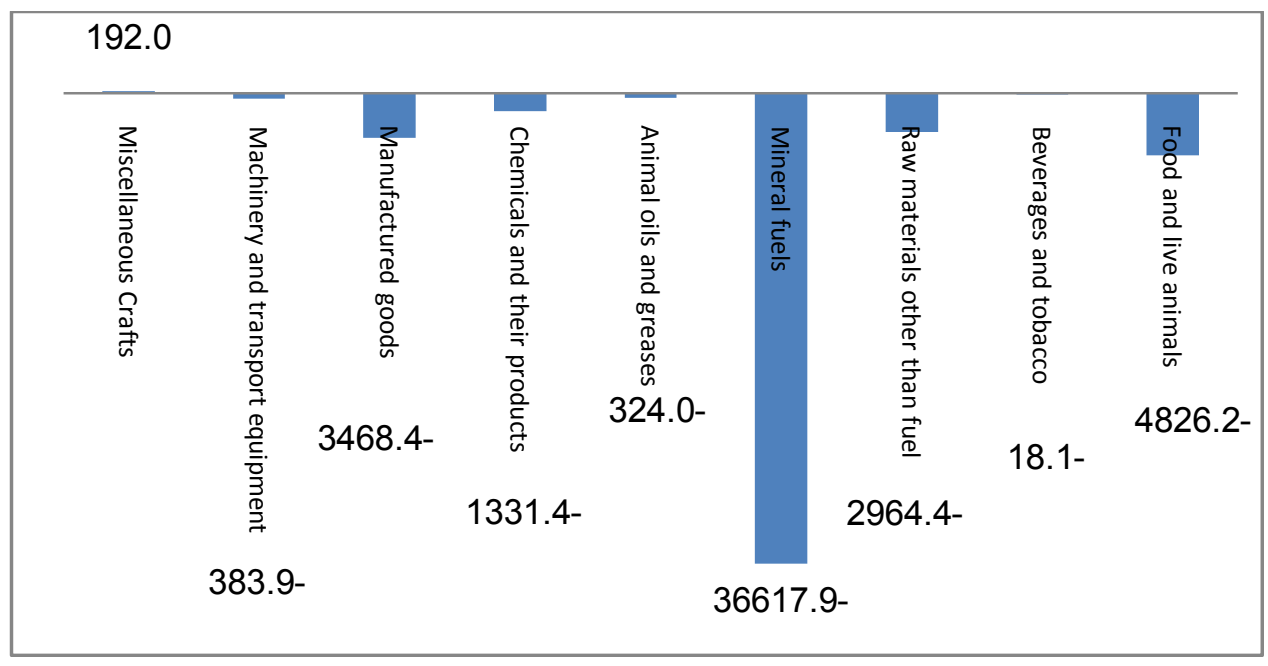

Fig 5:-Net trade balance between Syria and Russia for 2010:

5. Russia is not an export partner of Syria, according to the standard of commercial importance of exports: First: High price oil: where not all the economic agreements signed in the oil field until 2010, to improve Syria's oil exports to Russia. While the ratio of overall oil exports 50\%, The percentage of oil exports to Russia was 0\% for 2010. Second: Low Price Food and Animals contributed 29.13\% of total export to Russia in 2010. Based on the above, it could be concluded that there is no significant effect of the bilateral trade agreements on creating preferential advantages for Syria. In the end, it should be pointed out that the agreements alone are not responsible for bringing about this change, but rather the production lines in Syria, which are characterized by inflexibility, to the requirements of the export markets.

6. The bilateral trade agreements signed with Russia led Syria to rely heavily on Russian imports to secure the needs of its economy and its citizens, but its preservation of its position during the period of crisis is also due to the suspension of many countries from exporting to Syria because of economic sanctions imposed on them.

7. The trade balance goes in favor of Russia, because the import bill is larger than its export returns. Russia ranked $16^{\text {th }}$ among 17 countries, according to net trade balance standard. The first ranks showing the net trade balance are positive for the following countries: Iraq, Italy, France, Jordan, Germany and Saudi Arabia. Goods categories that contributed to the net negative trade balance with Russia are: mineral fuels, food, live animals, and manufactured goods.

\section{Recommendations:-}

1. Increasing the interest in activating the bilateral trade agreements with Russia, so that its purpose should be to increase Syrian exports to it in a way that maximizes the benefit of Syria from the Russian partner.

2. Studying the needs of the Russian market, and supporting Syrian industries that meet these needs, so that the contributor to increase Syrian exports, not only bilateral trade agreements but the quality of Syrian exports.

3. Working to address the imbalance in Syrian-Russian trade balance, by linking the imports from Russia with exports to it, which contributes to make Russia a real trading partner of Syria.

\section{Conclusion:-}

This study reviewed the bilateral trade agreements between Syria and Russia, as well as their impact on the position of Russia as an export partner of Syria. However, these agreements did not contribute to the promotion of this position, due to various reasons, the most important of them was: The weak effectiveness of these agreements in 
encouraging exports to Russia, and the weakness of the Syrian export industries, which were limited to commodities of low commercial prices, that made Russia the biggest beneficiary of these agreements, which ranked $2^{\text {nd }}$ among import partners of Syria, unlike its late rank $13^{\text {th }}$ among export partners.

\section{References:-}

1. Almadani, M. (2014). Russian intervention in the Syrian crisis. Scientific Journal of the Faculty of Economics. (4). University of Niles. Sudan.

2. Alsuwaidi, K. (2012). E-Views and Economic Analysis. Cultural Books House. First Edition. Amman , Jordan.

3. Anson, J., Fabozzi P. and Frank J. (2010). The Handbook of Traditional and Alternative Investment Vehicles: Investment Characteristics and Strategies. UK: John Wiley \& Sons.

4. Bagan, W. (2017). Syria in Russia's Foreign Policy in the 21st Century. Teka Kom. Politol. Stos. Międzynar. OL PAN, 12/1, 27-40.

5. Borah, A. (2017). Syria-Russia Relations during the Syrian Crisis. Imperial Journal of Interdisciplinary Research -IJIR-. 3(4).

6. Donaldson, R.H., Nogee J.L. and Nadkarni V. (2014). The Foreign Policy of Russia. Changing Systems, Enduring Interests, Routledge, London and New York.

7. Kozhanov N. (2014). Russian-Syrian Dialogue: Myths and Realities. Journal of the Middle East and Africa. 5 (1).

8. Maleky, M. (2015). Russian foreign policy towards the Syrian crisis. Master of Political Science unpublished. Faculty of Law and Political Science. Algeria: University of Gilali Bonn General.

9. Othman, S. and Mohammed, Z. (2015). The role of bilateral agreements in the development of Syrian-Russian trade relations. Tishreen University Journal for Research and Scientific Studies - Series of Economic and Legal Sciences. 3 (37).

10. Syrian statistical groups, [1998-2016].

11. Yu, B. (Jan. 2016). Russia-China Relations: Into the Syrian Storm: between Alliance and Alignment. Comparative Connections, 17 (3), 137-152.

12. Al-furat,(2017). Syrian-Russian relations. A long history of comprehensive coordination and a common vision of international issues. Al-Furat: A political journal published by Al-Wahda Foundation for Press, Printing, Publishing and Distribution - Deir Al-Zour, Syria. No. 2518, 2017-8.1. (Retrieved on: 24-12-2017). Available at: http://furat.alwehda.gov.sy/node/179350.

13. Ammar H (2016) Syria Ready to Become Hub for Russian Exports in the Middle East. Sputnik News, 25 April. (Retrieved on: 24-8-2016). Available at: https://sputniknews.com/middleeast/201604251038575397-syriarussian-goods-middle-east/

14. Ashawi, K. (2016) Russia sets up free trade zone with Syria. RT, 22 November. (Retrieved on: 29-11-2016). Available at: https://www.rt.com/business/367810-russia-syriafree-trade-deal/ .

15. Issa, Sami (2016). Russian-Syrian relations. Website of the Syrian newspaper Tishreen, (Retrieved on: 2-92017). Available at: www.tishreen.news.sy.

16. Khatib H (2016) Syria asks Russia to rebuild its energy sector. RT, 20 May. (Retrieved on: 15-11- 2016). Available at: https://www.rt.com/business/343783-syria-energycompanies-infrastructure/.

17. Oil \& Gas Technology (06th August, 2012). Russia-Syria reach oil agreement. (Retrieved on: 18-11-2017). Available at: http://www.oilandgastechnology.net/business-strategy-news/russia-syria-reach-oil-agreement.

18. Syrian Customs. Conventions. (Retrieved on: 1-2-2018). Available at: http://www.customs.gov.sy/agreements.php.

19. Syrian Export and Product Support and Development Authority, (2016). House for Syrian products in Russia soon. $21-12$ - 2016. (Retrieved on: 1-9-2018). Available at: http://edpa.gov.sy/?p=37.

20. Syrian Ministry of Finance. Syrian - Russian memorandum of understanding on the economic customs framework. (Retrieved on: 1-7-2018). Available at: http://www.syrianfinance.gov.sy/arabic/2079.html\&pr_docid=3715.

21. The Syrian Steps (2012) Forty-three agreements regulating Syrian-Russian relations. 25-4-2012. (Retrieved on: 21-8-2017). Available at: http://www.syriasteps.com/index.php?p=131\&id=85797. 